\title{
Isolated Splenic Tuberculosis: A Diagnostic Conundrum
}

\author{
Sahil Grover ${ }^{1}$, Yajur Arya ${ }^{1}$, Saurabh Gaba ${ }^{1}$, Monica Gupta ${ }^{1}$, Arshi Syal ${ }^{1}$ \\ 1. Internal Medicine, Government Medical College \& Hospital, Chandigarh, IND
}

Corresponding author: Monica Gupta, monicamanish2001@gmail.com

\begin{abstract}
Tuberculosis is an established cause of pyrexia of unknown origin and can implicate practically any human organ system. Splenic involvement is common in disseminated or miliary tuberculosis following hematogenous spread, but isolated splenic involvement is a very rare phenomenon. We report the case of a 30-year-old immunocompetent female who presented with high-grade fever and dull aching pain in the left hypochondrium for three months. Laboratory data provided no diagnostic information. Abdominal ultrasonography revealed an enlarged spleen with multiple small hypoechoic lesions that were corroborated on computed tomography. No pulmonary involvement or primary focus of infection was discernible elsewhere. Splenic fine needle aspiration cytology helped clinch a histopathological diagnosis of isolated splenic tuberculosis. Administration of anti-tubercular therapy resulted in resolution of the disease and an excellent outcome in our patient.
\end{abstract}

Categories: Internal Medicine, Infectious Disease

Keywords: spleen, isolated splenic tuberculosis, pyrexia of unknown origin

\section{Introduction}

Although the spleen is the third most common organ affected in miliary or disseminated tuberculosis after the lungs and liver, isolated splenic tuberculosis is a rare disease manifestation [1]. The symptoms of splenic tuberculosis are usually non-specific and misleading. Fever, abdominal pain, and weight loss are common, although asymptomatic cases have also been reported [2]. Pyrexia of unknown origin (PUO) is a frequently reported disease manifestation [1]. Early diagnosis of isolated splenic tuberculosis is hardly possible given its vague symptomatology. In addition, Mycobacterium tuberculosis infection is challenging to diagnose in the spleen due to bacterial sequestration. Thus, a high degree of suspicion is necessary in cases presenting with PUO and splenomegaly.

Review began 01/24/2021 Review ended 01/26/2021 Published 01/28/2021

\section{○ Copyright 2021}

Grover et al. This is an open access article distributed under the terms of the Creative Commons Attribution License CC-BY 4.0., which permits unrestricted use, distribution, and reproduction in any medium, provided the original author and source are credited.

\section{Case Presentation}

A 30-year-old female presented to the medicine department with complaints of fever and headache for three months, frequent bowel movements associated with abdominal pain, and generalized weakness for one month prior to presentation. Fever was insidious in onset, documented to be $101^{\circ} \mathrm{F}$, and was associated with chills, rigors, and night sweats. The headache was diffuse in nature without any blurring of vision, vomiting, or neck stiffness. Her abdominal pain was localized to the left upper quadrant and was dragging in nature, non-radiating, and gradually progressive. It was associated with three to four loose stools a day which were watery in nature and not associated with blood or mucus. There was no history of cough, expectoration, loss of weight, or anorexia. There was no history of close contact with a patient of tuberculosis. Past history was significant for type 2 diabetes mellitus diagnosed three months previously and she was taking oral hypoglycemic agents. Her personal history did not suggest any addiction or allergies, exposure to irritants, intravenous or oral drug abuse, exposure to birds and pets, or human immunodeficiency virus (HIV) infection.

Physical examination revealed an average built female with a pulse rate of 100 beats per minute, respiratory rate of 14 per minute, blood pressure of $110 / 60 \mathrm{mmHg}$, and an axillary temperature of $100.4^{\circ} \mathrm{F}$. On general physical examination, pallor was noted. There was no icterus, clubbing, lymphadenopathy, pedal edema, rash, scars, or sinuses. Abdominal examination revealed a non-tender, firm, enlarged spleen extending $4 \mathrm{~cm}$ below the costal margin. There was no evidence of hepatomegaly or free fluid in the abdomen. Respiratory system examination revealed bilaterally symmetrical air entry and normal vesicular breath sounds. Cardiovascular examination revealed normal heart sounds with no murmurs. Neck rigidity and other meningeal signs were absent. Ocular, ear, nose, and throat examinations were unremarkable. Gynecological examination was non-contributory. Examination of the spine did not reveal any spinal tenderness or palpable step-offs.

Initial laboratory investigations revealed a hemoglobin of $8.8 \mathrm{gm} / \mathrm{dL}$, platelet count of $99 \times 10^{9} / \mathrm{L}$, a total leukocyte count of $3.9 \times 10^{9} / \mathrm{L}$ (with normal differential counts), and erythrocyte sedimentation rate of 64 $\mathrm{mm}$ in the first hour. A peripheral blood smear was subsequently ordered which revealed a normocytic 


\section{Cureus}

normochromic picture. The blood sugars were well-controlled, and her renal and liver function tests, serum electrolytes, and coagulation profile were within normal limits. C-reactive protein was $90 \mathrm{mg} / \mathrm{dL}$. Cultures of blood and urine were sterile. Serologic tests for hepatitis B, hepatitis C, and HIV were negative. Serum calcium, vitamin D, and angiotensin-converting enzyme levels were within normal range. Serological tests for other febrile tropical illnesses including dengue, malaria, scrub typhus, typhoid, brucellosis, and recombinant kinesin antigen (rK39) for leishmaniasis were negative. Chest radiography revealed no abnormalities. No acid-fast bacilli were detectable on sputum Ziehl-Neelsen (ZN) stain, and polymerase chain reaction (PCR) for $M$. tuberculosis was negative. The tuberculin skin test, however, showed an induration of $12 \times 14 \mathrm{~mm}$. It was considered positive as India is a high-risk country.

Ultrasonography of the abdomen was suggestive of splenomegaly measuring $16.6 \mathrm{~cm}$, with multiple scattered well-defined hypoechoic lesions of variable sizes. Computed tomography (CT) scan of chest and abdomen revealed multiple well-defined scattered hypoechoic lesions of variable sizes in an enlarged spleen (Figure 1). The liver was normal with homogenous echogenicity. No mediastinal or abdominal lymphadenopathy was noted and the lung parenchyma was unremarkable.

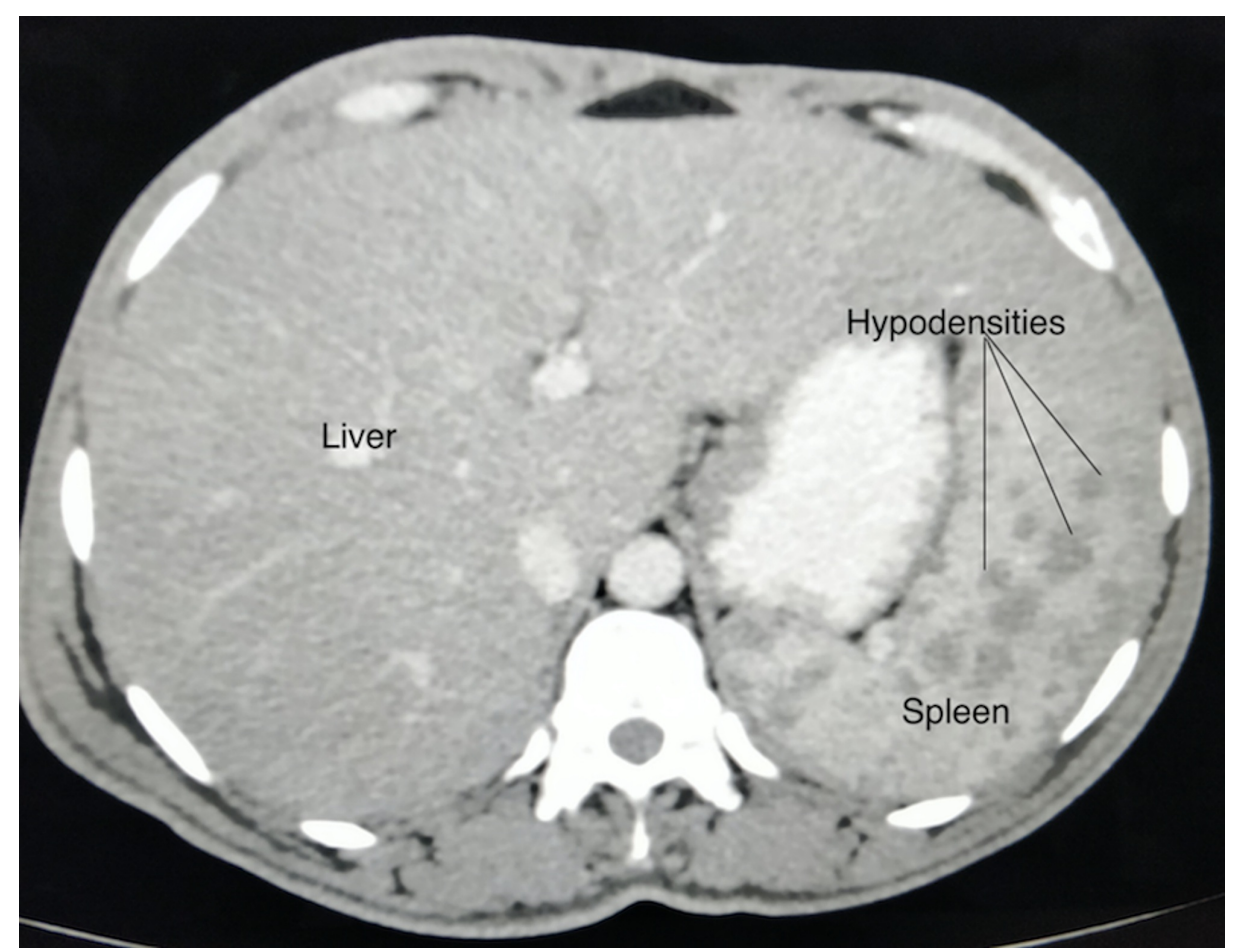

\section{FIGURE 1: Abdominal CT scan showing splenomegaly with multiple hypoechoic lesions.}

CT, computed tomography

The prominent differential possibilities in our case were lymphomatous infiltration, tuberculosis, sarcoidosis, and fungal infection in addition to multiple pyogenic abscesses.

A two-dimensional echocardiography was performed to rule out infective endocarditis and was found to be normal. Bone marrow aspiration and biopsy revealed mild megaloblastosis without any evidence of granulomas, acid-fast bacilli, or marrow infiltration. An ultrasound-guided fine needle aspiration cytology (FNAC) of the spleen was carried out, which revealed fragments of lymphoid and endothelial cells. A few epithelioid cell granulomas were also demonstrated (Figures 2, 3). Hence, a diagnosis of granulomatous inflammation was made. 


\section{Cureus}

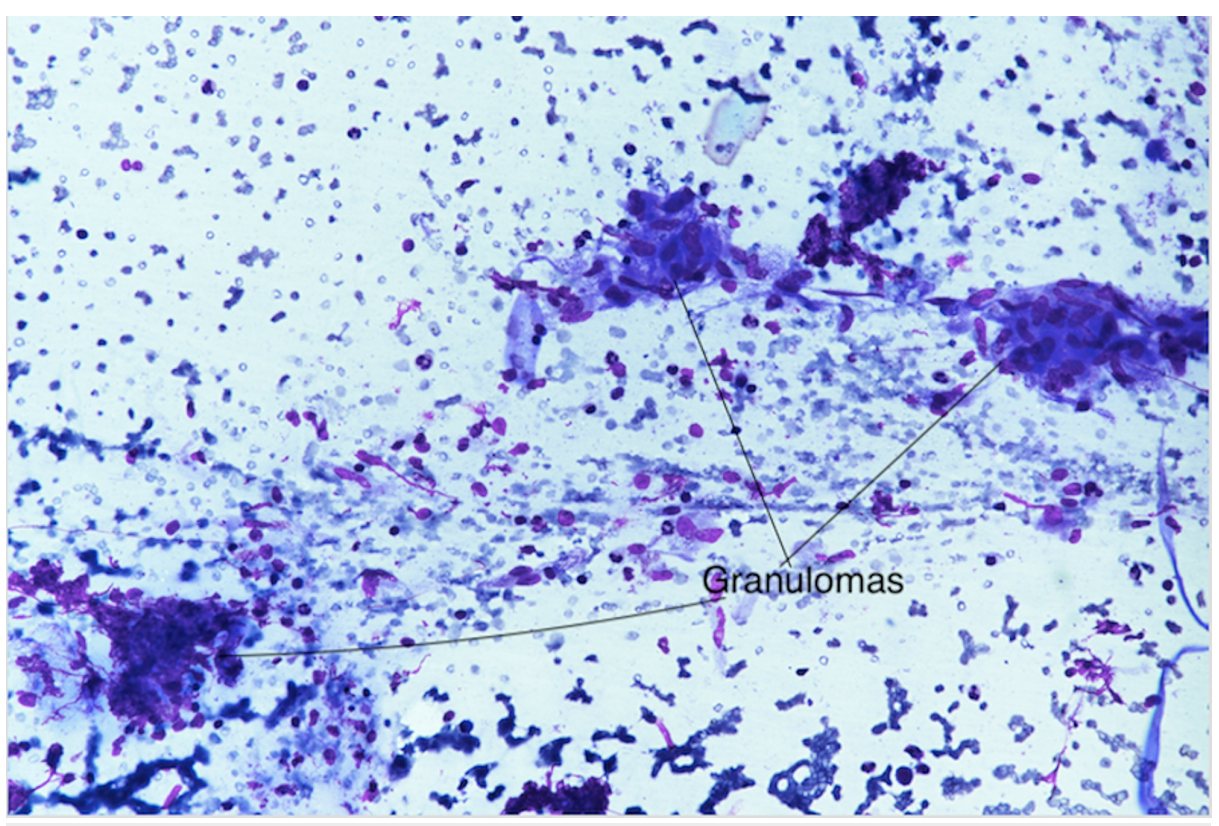

FIGURE 2: Splenic aspirate showing epithelioid cell granulomas.

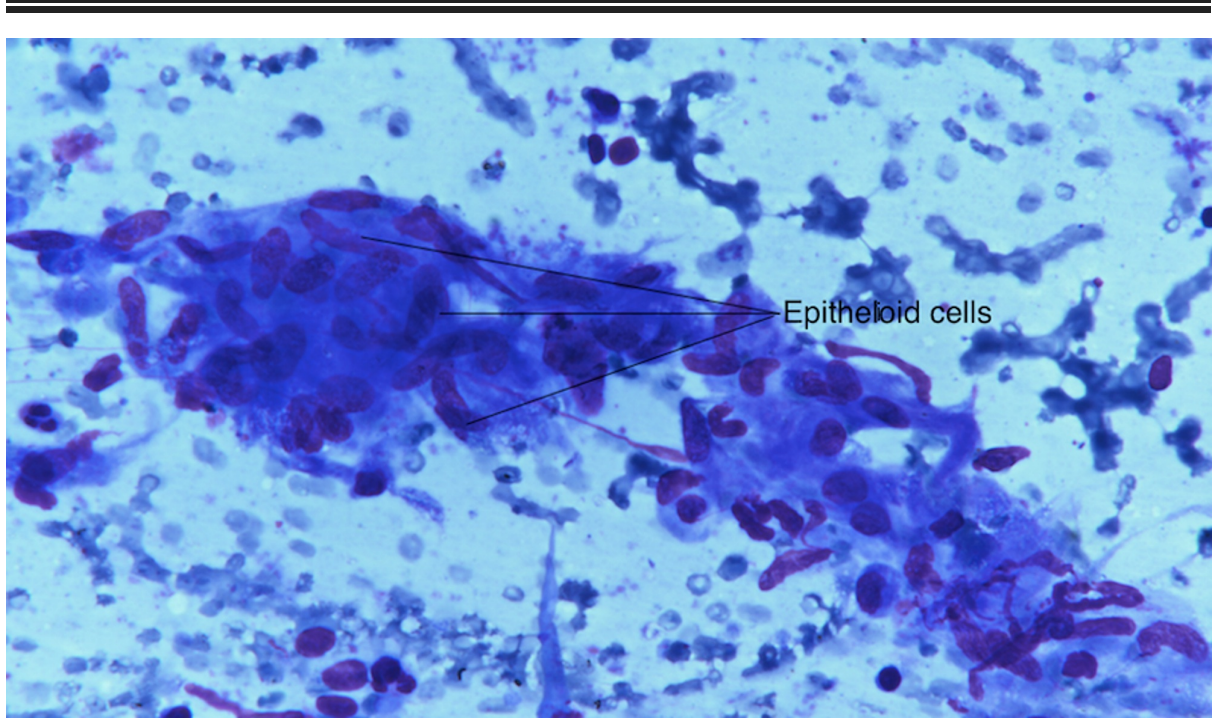

FIGURE 3: Splenic aspirate showing epithelioid cells.

No bacterial or fungal organisms were cultured from the aspirate. ZN staining for acid-fast bacilli of the aspirate was negative, however, PCR for M. tuberculosis of the aspirate was positive. The patient was started on standard quadruple anti-tubercular therapy (ATT) comprising isoniazid, rifampicin, pyrazinamide, and ethambutol for two months in the intensive phase followed by isoniazid and rifampicin for four months in the continuation phase. Her fever subsided by the end of two weeks. Repeat ultrasound at two months showed significant regression of the lesions as well as significant improvement in general well-being. ATT was administered for a total duration of six months.

\section{Discussion}

Tuberculosis is a chronic infectious disease with a widespread prevalence in resource-poor countries. Although its incidence is on the decline in many developed nations, it is still a major public health problem in many developing countries. Primary splenic (isolated) tuberculosis is now a recognized entity, although it is extremely rare, especially in immunocompetent patients. Therefore, one must exclude immunosuppression, repeated pyogenic infections, prior splenic trauma or splenic defects, and hemoglobinopathies such as sickle cell disease [3]. To date, only a limited number of case reports have been published related to isolated splenic tuberculosis, as described below (Table 1). 


\section{Cureus}

\begin{tabular}{|c|c|c|c|c|c|}
\hline $\begin{array}{l}\text { S. } \\
\text { No. }\end{array}$ & Authors & $\begin{array}{l}\text { Patient } \\
\text { details } \\
\text { (Age/Gender) }\end{array}$ & Presenting symptoms/signs & Diagnosis & Management \\
\hline 1. & $\begin{array}{l}\text { Udgaonkar } \\
\text { et al. [2] }\end{array}$ & $38 / F$ & $\begin{array}{l}\text { Asymptomatic and incidentally diagnosed on } \\
\text { USG abdomen }\end{array}$ & $\begin{array}{l}\text { ZN staining on USG- } \\
\text { guided aspiration of the } \\
\text { spleen }\end{array}$ & Six months of ATT \\
\hline 2. & $\begin{array}{l}\text { Basa et al. } \\
\text { [3] }\end{array}$ & $27 / M$ & $\begin{array}{l}\text { Generalized weakness, anorexia, weight loss, } \\
\text { night sweats, splenomegaly, and } \\
\text { thrombocytopenia }\end{array}$ & $\begin{array}{l}\text { Histopathology of } \\
\text { splenectomy specimen }\end{array}$ & $\begin{array}{l}\text { Splenectomy } \\
\text { followed by ATT }\end{array}$ \\
\hline 3. & $\begin{array}{l}\text { Wangai et } \\
\text { al. [4] }\end{array}$ & $26 / \mathrm{M}$ & PUO & CNB of the spleen & Six months of ATT \\
\hline 4. & $\begin{array}{l}\text { Gupta et } \\
\text { al. [5] }\end{array}$ & $62 / F$ & Low-grade fever and LUQ pain & $\begin{array}{l}\text { USG-guided FNAC of } \\
\text { the spleen }\end{array}$ & Six months of ATT \\
\hline 5. & $\begin{array}{l}\text { Dhibar et } \\
\text { al. [6] }\end{array}$ & 30/M & LUQ pain, weight loss and splenomegaly & $\begin{array}{l}\text { USG-guided FNAC of } \\
\text { the spleen }\end{array}$ & Six months of ATT \\
\hline 6. & $\begin{array}{l}\text { Rao et al. } \\
\text { [7] }\end{array}$ & $17 / F$ & PUO & $\begin{array}{l}\text { FDG-PET and Trucut } \\
\text { biopsy of the spleen }\end{array}$ & Nine months of ATT \\
\hline 7. & $\begin{array}{l}\text { Kumar et } \\
\text { al. [8] }\end{array}$ & 23/F & $P U O$ and $L U Q$ pain & $\begin{array}{l}\text { Histopathology of } \\
\text { splenectomy specimen }\end{array}$ & $\begin{array}{l}\text { Splenectomy } \\
\text { followed by six } \\
\text { months of ATT }\end{array}$ \\
\hline 8. & $\begin{array}{l}\text { Mandal et } \\
\text { al. [9] }\end{array}$ & $20 / F$ & PUO, weight loss, and splenomegaly & $\begin{array}{l}\text { USG-guided FNAC of } \\
\text { spleen }\end{array}$ & Nine months of ATT \\
\hline 9. & $\begin{array}{l}\text { Mishra et } \\
\text { al. [10] }\end{array}$ & 28/M & LUQ pain & $\begin{array}{l}\text { Frozen section of the } \\
\text { spleen during } \\
\text { laparotomy }\end{array}$ & $\begin{array}{l}\text { Splenectomy } \\
\text { followed by ATT }\end{array}$ \\
\hline 10. & $\begin{array}{l}\text { Zhan et al. } \\
\text { [11] }\end{array}$ & $36 / \mathrm{M}$ & PUO with splenomegaly & CNB of the spleen & Six months of ATT \\
\hline 11. & $\begin{array}{l}\text { Kumar et } \\
\text { al. [12] }\end{array}$ & $51 / \mathrm{M}$ & PUO and LUQ pain with splenomegaly & $\begin{array}{l}\text { CT-guided FNAC of the } \\
\text { spleen }\end{array}$ & Six months of ATT \\
\hline 12. & $\begin{array}{l}\text { Kundu et } \\
\text { al. [13] }\end{array}$ & 13/M & LUQ pain with splenomegaly & FNAC of the spleen & $\begin{array}{l}\text { Splenectomy } \\
\text { followed by eight } \\
\text { months of ATT }\end{array}$ \\
\hline
\end{tabular}

\section{TABLE 1: Case reports on isolated splenic tuberculosis in the last decade.}

M, male; F, female; USG, ultrasound; ZN, ZiehI-Neelsen; ATT, anti-tubercular therapy; PUO, pyrexia of unknown origin; CNB, core needle biopsy; LUQ, left upper quadrant; FNAC, fine needle aspiration cytology; FDG-PET, fluorodeoxyglucose-positron emission tomography; CT, computed tomography

Splenic tuberculosis can present with a myriad of signs and symptoms ranging from constitutional symptoms, such as fatigue, weight loss, splenomegaly, or PUO, to grave complications including hypersplenism, portal hypertension, and splenic rupture [4]. Generally, splenic tuberculosis is associated with reduced cell counts, as seen in our patient; however, polycythemia has also been documented. The initial imaging modality of choice is abdominal ultrasound as it is cost-effective and helps in characterizing the lesion. Splenic lesions typically present as multiple, hypoechoic lesions which may be tuberculomas or abscesses. Abdominal CT scan has higher diagnostic accuracy and can aid in superior delineation of splenic lesions. Diagnosis is further clinched by histopathological examination of the lesions. In various reports (Table 1), either FNAC, laparoscopic, or imaging-guided core needle biopsy (CNB) or splenectomy specimens have been examined for diagnostic confirmation [14]. CNB has a higher diagnostic yield and superior accuracy compared to FNAC in characterizing splenic lesions [15]. FNAC has a lower risk of bleeding compared to CNB.

ATT forms the mainstay of management in splenic tuberculosis. Duration of treatment varies but regimens generally lasting for six to nine months are deemed satisfactory. In patients who do not respond to medical therapy alone, splenectomy forms a viable option. A paradoxical phenomenon of exaggerated inflammatory 
symptoms, called immune reconstitution inflammatory syndrome, can rarely be seen on initiation of medical therapy. This may present as either worsening of existing lesions or development of new lesions, or as worsening of clinical or radiological findings following initiation of ATT [16].

\section{Conclusions}

Isolated splenic tuberculosis is a rare presentation of tuberculosis and has been occasionally described in the literature. Common symptoms include fever, abdominal pain, diarrhea, and generalized weakness. Significant diagnostic delays usually occur due to its inconsistent symptomatology. Ultrasound and CT scan of the abdomen are the first-line investigations. Tissue aspiration or biopsy are indispensable for diagnostic confirmation in cases where splenectomy is not performed. Amplification modalities including PCR techniques are useful for establishing diagnosis in ZN stain-negative cases. Administration of ATT can result in a favorable outcome and can preclude the need of a splenectomy. Physicians should be cognizant of isolated splenic affliction in tuberculosis, and tissue diagnosis should be carried out as early as possible in suspected cases.

\section{Additional Information \\ Disclosures}

Human subjects: Consent was obtained or waived by all participants in this study. Conflicts of interest: In compliance with the ICMJE uniform disclosure form, all authors declare the following: Payment/services info: All authors have declared that no financial support was received from any organization for the submitted work. Financial relationships: All authors have declared that they have no financial relationships at present or within the previous three years with any organizations that might have an interest in the submitted work. Other relationships: All authors have declared that there are no other relationships or activities that could appear to have influenced the submitted work.

\section{References}

1. Nayyar V, Ramakrishna B, Mathew G, Williams RR, Khanduri P: Response to antituberculous chemotherapy after splenectomy. J Intern Med. 1993, 233:81-3. 10.1111/j.1365-2796.1993.tb00653.x

2. Udgaonkar U, Kulkarni S, Shah S, Bhave S: Asymptomatic, isolated tubercular splenic abscess, in an immunocompetent person. Indian J Med Microbiol. 2010, 28:172-3. 10.4103/0255-0857.62501

3. Basa JV, Singh L, Jaoude WA, Sugiyama G: A case of isolated splenic tuberculosis . Int J Surg Case Rep. 2015, 8:117-9. 10.1016/j.ijscr.2014.10.050

4. Wangai F, Achieng L, Otieno G, Njoroge J, Wambaire T, Rajab J: Isolated splenic tuberculosis with subsequent paradoxical deterioration: a case report. BMC Res Notes. 2017, 10:162. 10.1186/s13104-0172483-2

5. Gupta P, Dhaka N, Rohilla M: Isolated splenic tuberculosis presenting as an unusual splenic mass . Int J Mycobacteriol. 2018, 7:397-8. 10.4103/ijmy.ijmy_120_18

6. Dhibar DP, Chhabria BA, Gupta N, Varma SC: Isolated splenic cold abscesses in an immunocompetent individual. Oman Med J. 2018, 33:352-5. 10.5001/omj.2018.64

7. Rao A, Mallarajapatna G, Godehal S, Shivakumar S: Isolated splenic tuberculosis detected only on FDG-PET . BJR Case Rep. 2017, 3:20150238. 10.1259/bjrcr.20150238

8. Kumar S, Pai AG, Tungenwar PN, Bhandarwar AH: Isolated primary tuberculosis of spleen-a rare entity in the immuno-competent patient. Int J Surg Case Rep. 2017, 30:93-6. 10.1016/j.ijscr.2016.11.038

9. Mandal SK, Ganguly J, Sil K, Chatterjee S: Isolated splenic tuberculosis in an immunocompetent patient BMJ Case Rep. 2014, 2014:2013203271. 10.1136/bcr-2013-203271

10. Mishra H, Pradeep R, Rao GV, Anuradha S, Nageshwar Reddy DN: Isolated tuberculosis of the spleen: a case report and review of literature. Indian J Surg. 2013, 75:235-6. 10.1007/s12262-012-0511-y

11. Zhan F, Wang CJ, Lin JZ, et al.: Isolated splenic tuberculosis: a case report. World J Gastrointest Pathophysiol. 2010, 1:109-11. 10.4291/wjgp.v1.i3.109

12. Kumar A, Kapoor VK, Behari A, Verma S: Splenic tuberculosis in an immunocompetent patient can be managed conservatively: a case report. Gastroenterol Rep (Oxf). 2018, 6:72-4. 10.1093/gastro/gov058

13. Kundu PR, Mathur SK, Singh S, Duhan A, Aggarwal G, Sen R: Isolated tuberculous splenic abscess in an immunocompetent individual. Asian Pac J Trop Med. 2011, 4:81-2. 10.1016/S1995-7645(11)60040-0

14. Imani Fooladi AA, Hosseini MJ, Azizi T: Splenic tuberculosis: a case report. Int J Infect Dis. 2009, 13:273-5. 10.1016/j.ijid.2008.11.002

15. Sammon J, Twomey M, Crush L, Maher MM, O'Connor OJ: Image-guided percutaneous splenic biopsy and drainage. Semin Intervent Radiol. 2012, 29:301-10. 10.1055/s-0032-1330064

16. Cheng VC, Ho PL, Lee RA, et al.: Clinical spectrum of paradoxical deterioration during antituberculosis therapy in non-HIV-infected patients. Eur J Clin Microbiol Infect Dis. 2002, 21:803-9. 10.1007/s10096-002$0821-2$ 